\section{P. Gjersvik og medarbeidere svarer:}

Vi takker Gudjon Gunnarson for et morsomt innlegg, som bekrefter våre to poeng: at maritime begreper er lite egnet til å beskrive kirurgisk snittføring, og at skalpellen må brukes på riktig måte.

\section{Petter Gjersvik}

petter.gjersvik@medisin.uio.no

Ingrid Roscher

Kim Alexander Tønseth

Petter Gjersvik (f. 1952) er spesialist i hud- og veneriske sykdommer, førsteamanuensis og undervisningsleder i hud-og veneriske sykdommer ved Institutt for klinisk medisin, Universitetet i Oslo.

Ingen oppgitte interessekonflikter.

Ingrid Roscher (f. 1957) er spesialist i hud- og veneriske sykdommer og overlege ved Seksjon for hudsykdommer, Oslo universitetssykehus. Ingen oppgitte interessekonflikter.

Kim Alexander Tønseth (f. 1974) er spesialist i plastikkirurgi og er avdelingssjef ved Avdeling for plastikk- og rekonstruktiv kirurgi, Oslo universitetssykehus.

Ingen oppgitte interessekonflikter.

\section{Re: Eit enkelt spørsmål}

I Tidsskriftet nr. 19/2014 leste jeg et intervju med professor Bjørn Reino Olsen, som jobber på Harvard Medical School. Intervjuet var interessant og morsomt. Jeg la merke til at professor Olsen er 74 år gammel og fremdeles yrkesaktiv. I Norge må man slutte sin legevirksomhet når man er 70 år. Dette synes jeg er aldersdiskriminering. I flere andre land, som USA, har man opphevet aldersgrensene i arbeidslivet.

Jeg vil at Legeforeningen skal ta denne saken opp med norske myndigheter; leger, som selv ønsker, må kunne fortsette vår legevirksomhet etter fylte 70 år. Dersom man ikke kommer til enighet, synes jeg saken bør tas for retten. Jeg synes at det norske medisinmiljø mister veldig mye hvis folk som er på topp faglig, og er fysisk og psykisk i god form, må slutte når de er 70 år. Ikke bare det, men som oftest bortfaller autorisasjonen når legen fyller 75 år.

Jeg har hatt den ære å jobbe med flere kolleger som aldri skulle fått lov til å slutte da de var 70 år. Jeg synes at man heller skulle motivere dem til å fortsette å jobbe. Jeg tillater meg bare å nevne et par kolleger som jeg har jobbet sammen med på Haukeland sykehus: professor Ole Jørgen Ohm, doktor Ole Martin Pedersen, professor Svein Ødegård, professor Gunnar Kvam og flere andre. De var så store innen norsk medisin at deres avgang med pensjon var et kolossalt tap, ikke bare for Haukeland sykehus, men for hele det norske medisinske miljø.

\section{Grzegorz Gradek}

gradek@online.no

Grzegorz Gradek (f. 1953) er privatpraktiserende spesialist ved Hjerte og lungesenteret, Bergen.

Ingen oppgitte interessekonflikter.

\section{Litteratur}

1. Homlong L. Eit enkelt spørsmål. Tidsskr Nor Legeforen 2014; 134: 1838-40.

\section{Re: En integrert forståelse av subjektive lidelser $\mathrm{i}$ klinisk praksis}

I denne kronikken bruker forfatterne begrepet «subjektive lidelser» (1). Jeg mener dette er et farlig begrep i medisinen. Man står i fare for å overse viktige sykdommer fordi man allerede har skapt seg en forklaringsmodell som låser pasienten i et teoretisk modellsystem det kan være vanskelig å komme ut av. Hvor mange lidelser har ikke med tiden vist seg å ha biologiske forklaringer bare man leter nøye nok? Og hvem ville ansett slike modeller like relevante ved behandling av mer anerkjente sykdommer som kreft eller MS?

Ved å kalle dette integrert forståelse, gir forfatterne inntrykk av at man har tatt alle forhold i betraktning, mens det motsatte ofte er tilfellet. Sykdommen myalgisk encephalomyelitis (ME) er et godt eksempel på en ofte misforstått eller «subjektiv» lidelse, der mange velger å bruke psykosomatiske forklaringsmodeller til tross for at kunnskapsmengden om sykdommens biologiske basis egentlig er stor (2). Dette oppfatter jeg som en form for hersketeknikk som sjelden tjener pasienten, men derimot gir legen, helsevesenet og ikke minst de økonomiske aktører i samfunnet et overtak på en lidende pasientgruppe. Som man tidligere nylig har vært inne på i Tidsskriftet (3), er medisinen full av myter. Jeg tror dessverre ikke at fokusering på mestringsstrategier for å intervenere i de postulerte vedlikeholdsfaktorer for subjektiv lidelse vil bidra til økt forståelse av kompliserte biologiske tilstander, og derfor heller ikke vil bidra til å avlive noen medisinske myter. Snarere tvert imot.

\section{Hanne Qvist}

hanne.qvist@gmail.com

Hanne Qvist (f. 1962) er lege og dr. med.

Ingen oppgitte interessekonflikter

Litteratur

1. Tveråmo A, Johnsen IB, Meland E. En integrert forståelse av subjektive lidelser i klinisk praksis. Tidsskr Nor Legeforen 2014; 134: 2174-6.

2. Hooper M. Myalgic encephalomyelitis: a review with emphasis on key findings in biomedical research. J Clin Pathol 2007; 60: 466-71.

3. Brean A. Myteknuserne. Tidsskr Nor Legeforen 2014; 134: 1633.

\section{A. Tveråmo og medarbeidere svarer:}

Vår kronikk tar utgangspunkt i skolemedisinens forklaringsproblemer. Vi er i startfasen av å utvikle en bredere forklaringsmodell. Leger er opplært etter en biomedisinsk modell, der en diagnose kan stilles ut i fra pasientens subjektive symptomer, og legens objektive funn ved klinisk undersøkelse, supplert med lab- og radiologisk diagnostikk. Denne informasjonen danner grunnlaget for en diagnose, som igjen er koblet til en skolemedisinsk behandling.

Vi påpeker at den skolemedisinske modellen ved symptomlidelser overser mange observasjoner og fenomener. Vi prøver å utvikle et verktøy, slik at vi kan objektivere disse; det vil si samle, gruppere, analysere og tolke. Kanskje dette kan bidra til å avdekke og gradere en allostatisk komponent som én av flere bakenforliggende mekanismer for individets symptomprofil. Utredning av allostatisk load utelukker ikke andre patogenetiske mekanismer.

Vi har ikke lagt verdiladning i begrepet «subjektiv lidelse». Begrepet har tatt utgangspunkt i «subjektive helseplager» (Subjective Health Complaints, SHC) som er etablert i medisinsk psykologi overfor stressrelaterte lidelser (1). SHC-scoringsskjemaet inneholder derimot ikke avhengighetstilstander som over-/underspising, eller spill- og rusavhengighet. Siden disse tilstandene er relatert til individets problemer med selvregulering av allostatisk load, ønsker vi å inkludere disse i vår integrerte helseforståelse. Med «subjektiv lidelse» mener vi da SHC pluss avhengighetstilstander.

Med integrert helseforståelse mener vi at stress- og mestringsteori er bygd inn i den biopsykososiale helsemodellen. Vi mener ikke at vi har en universell teori om alt, som utelukker andre forstå- 